\title{
The Relationship between Financial Ratios and Sporting Performance in Italy's Serie A
}

\author{
Andrea Rey ${ }^{1} \&$ Francesco Santelli ${ }^{2}$ \\ ${ }^{1}$ Department of Economics, Management Institutions, University of Naples Federico II, Napoli, Campania, Italy \\ ${ }^{2}$ Department of Statistics, University of Naples Federico II, Napoli, Campania, Italy \\ Correspondence: Andrea Rey, Department of Economics, Management Institutions, University of Naples \\ Federico II, Napoli, Campania, Italy. E-mail: andrea.rey@unina.it
}

Received: September 18, 2017

Accepted: November 15, 2017

Online Published: November 20, 2017

doi:10.5539/ijbm.v12n12p53

URL: https://doi.org/10.5539/ijbm.v12n12p53

\begin{abstract}
In the last few years, the economic literature has shown an increasing interest in the football industry. Therefore, the purpose of this paper is to investigate the relationship between financial performance and sporting performance in Italian football, by investigating the statistical evidences.

In order to do it, the financial indicators and sporting performance will be examined with regards to 29 clubs in Serie A (the highest official Italian football league) that participated in the league during the period 2011-2015. The data are collected from the financial statements of the clubs and have been processed into financial ratio indicators. The empirical statistical analysis has been carried out by means of correlation and regression analysis.

This research study empirically reveals that Italian clubs that are in good financial health, not indebted and that record higher revenues achieve the best sporting performance. This process is consistent with the "virtuous circle" theorized by the academic literature.

The application of this work can be extended to other national leagues by adding new ratios. On the other hand, the main limitation is related to the fact that the entry of foreign investors in recent years to Serie A could change this trend.
\end{abstract}

Keywords: Financial performance, Football, Ratio analysis, Serie A, Sporting performance

\section{Introduction}

In the last few years, the economic literature has shown an increasing interest in the football industry. Sloane (1971) was the first scholar to apply economic theory to the football industry, particularly to the case of British professional football. Recent research has examined the financial performance (Rohde \& Breuer, 2016) or the relationship between their ownership structures and their economics and sporting performance of football clubs (Wilson \& Plumley, 2013).

The purpose of this paper is to investigate the relationship between financial performance and sporting performance in Italian football. In order to achieve this, we analyse the financial indicators and performance of clubs that have participated in Serie A during the period 2011-2015. The most commonly used method for financial statement analysis is ratio analysis. Ratio analysis is considered as "the expression and mathematical interpretation of the relationship between two items aimed to be examined in the financial statements" (Ecer \& Boyukaslan, 2014).

First, we have summarised the available literature concerning the economic theory behind professional sports leagues. We specify the differences between the win maximization view and the profit maximization view. In addition, we trace the characteristics that have led the literature to consider football as a "social business" (Morrow, 2013).

Subsequently, our paper focuses on the evolutionary financial profiles of the Italian football industry. Nowadays, European clubs are moving towards a profit-led approach and becoming healthier. However, this trend is progressing much more slowly in Italy (Boeri \& Severgnini, 2014). This is also since Italian football is strongly related to club owners whose primary goals are not related to profit but to social returns. Therefore, we provide an overview of social aspects of the Italian football industry. We also analyse the financial and economic sides of 
Italian football.

Finally, in the fourth section we examine the association that exists between the on-field performance and financial results of clubs. There are many subjective indications that suggest that the sporting performance of clubs and their off-field financial success are closely associated.

\section{The Economic Theory behind Professional Sports Leagues}

\subsection{Win Maximization vs Profit Maximization: A Literature Review}

In the sport industry, the earliest theoretical studies were made in the United States (Rottenberg, 1956) (Neale, 1964). Sloane (1971) was the first scholar to apply economic theory to the football industry, particularly to the case of British professional football. Then, Késenne (1994) studied the implications of the win maximizing hypothesis in professional team sports.

From this theoretical literature, scholars began to make the first comparisons with European models (Késenne, 1996). Studies then pointed out the differences that exist between the various sports in Europe, highlighting a strong detachment and gap between North American and European models (Hoehn \& Szymanski, 1999) (Andreff, 2011) (Wilson \& Plumley, 2013), although "the European model is and will remain unique, but there appears to be convergence on certain features" (Andreff \& Staudohar, 2000).

However, there are several differences between the two models. The literature underlines that "the American sports model operates a draft system where the best performing rookie is assigned to the worst performing team. Furthermore, American sports leagues operate under salary caps, share television revenue equally and compete almost exclusively in domestically structured leagues" (Andreff \& Staudohar, 2000). The aim of these rules is to increase the competitiveness of all the franchises in the league. From this, it is reasonable to suggest that North American leagues and team owners aim to maximize profit, paying close attention to the revenues and costs generated during the season (Brunkhorst \& Fenn, 2010).

By contrast, the literature underlines that the European sports model is more closely related to utility or "win" maximisation, especially in football leagues. Garcia del Barro \& Szymanski (2006) suggest that "The omission of features such as salary caps and revenue sharing in the European model arguably makes it a more attractive investment opportunity, particularly for utility maximisers whose desire for short-term sporting success is funded through the purchase of better players who command higher salaries".

The fact that economic and financial performance are put in the background compared to sporting performance means that those who invest in the sport industries in Europe do so with the aim of gaining some returns that are not strictly economic or financial but social.

Morrow (2013) says that the football is a "social business" that should be interpreted broadly. The analysis should not be restricted just to the cost of the sporting association.

Gelmini (2014) also underlined how the needs of stakeholders in the sports business are often specific to the individuals and organisations involved. Some people decide to invest in football clubs for reasons that are extra-financial and related more to social benefit or to satisfy their own personal needs (Note 1) rather than economic ones. An example is the case of lenders to clubs who are oriented not so much to the generation of significant cash flows, but rather to social or personal gain of a non-financial nature.

Therefore, the football industry cannot be summarized as just a get-together moment or a trivial sporting event. The world of football is full of content that goes beyond the on-field aspect.

\section{Football Industry in Italy}

Italian football industry historically has been very far from what today we could define as a business healthy and orientated to the "profit" maximization (Boeri \& Severgnini, 2014).

Serie A league has been characterized in recent decades by clubs whose ownership was highly concentrated by holding groups or individual (Baroncelli \& Caruso, 2011) (Note 2). Since football is widely reported to be economically unhealthy or non-profitable, it has been used in Italy as a propaganda tool by those large families (Note 3) who have been in power and who have been part of the Italian economic and political establishment.

As already mentioned above, there are several authors (Morrow, 2013) (Sanders, Heys, Ravenscroft, \& Burdsey, 2014) who consider football as a "social business" but in the "Country of emigration from the Southern to Northern Italy, perhaps the typhus is more than anywhere else a recognition and social success vehicle" (Forgione, 2015) (Note 4).

Therefore, if the Italian football industry has been characterized mainly owners whose sole purposes were to 
promote their image and to make their business more inspired by the "win maximization" (Note 5), today there has been a significant turnaround. Thanks to stricter standards promoted by the FIGC (Note 6) and UEFA, Italian football clubs are moving towards a profit-led approach.

However, even if it could highlight that 8 teams returned a net profit in 2014 $\backslash 2015$, Serie A totalled collective losses (Note 7) for $€ 240,4 \mathrm{~m}$ (Figure 1). It is worsened by $12 \%$ respect the previous year. However, this income statement item has improved in the last five years.

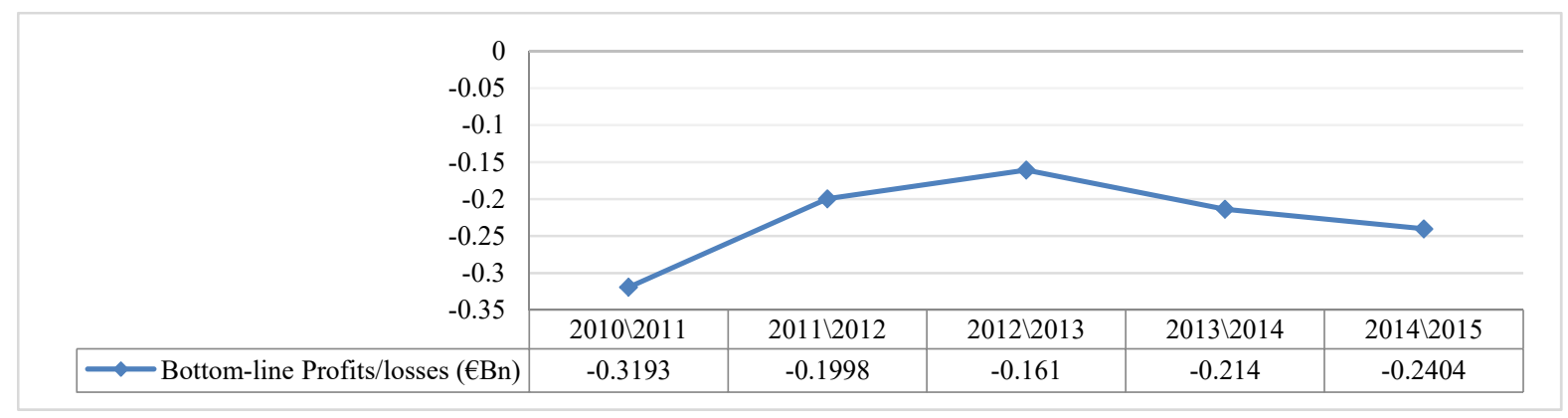

Figure 1. Evolution of Serie A Net profit/losses (Data in $€$ billion)

But what is causing this slowdown in the run-up to the change of the Italian football industry towards a greater level of health? While the investments (total assets) increased (Figure 2), on the other hand there was not that revenues increase expected (Figure 3). The total amount of revenues has remained constant and this does not allow to increase the wages of players.

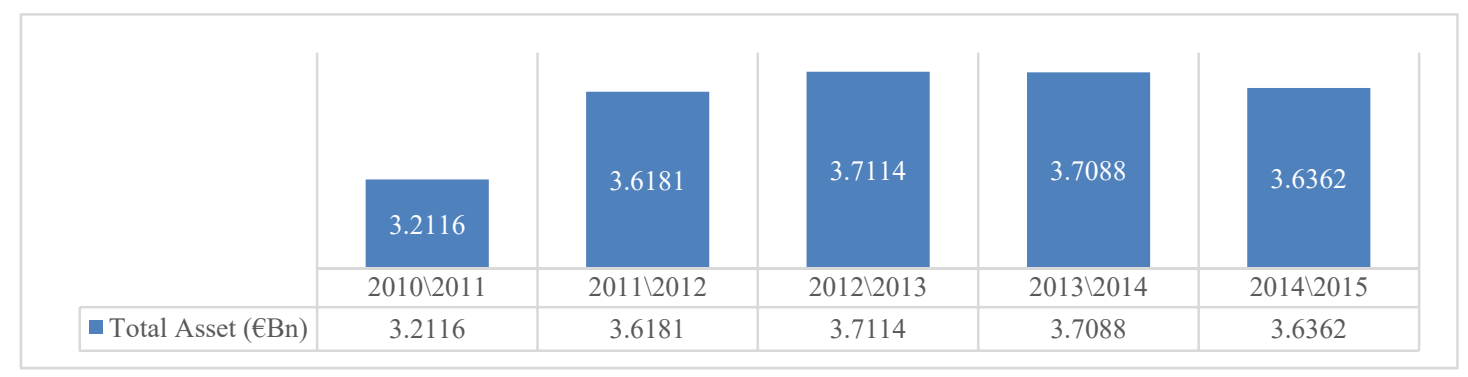

Figure 2. Evolution of Serie A total asset (Data in $€$ billion)

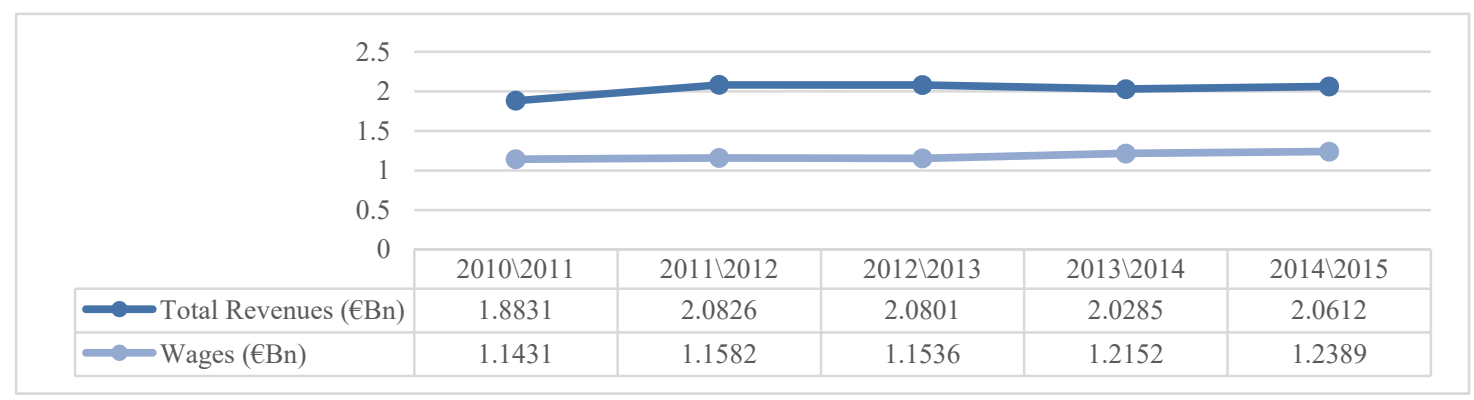

Figure 3. Evolution of Serie A Total Revenues and Wages (Data in € billion)

In fact, doing a comparison with the major European leagues, we note that to date the Serie A suffer this lack of efficiency that turns into stagnation in terms of both revenues and wages.

Compared to the others four major European leagues (Figure 4), the Serie A shows by far a lower amount of revenues compared to German Bundesliga, La Liga and the Premier League. The series A is globally fourth in 
total revenues, only ahead of the French championship.

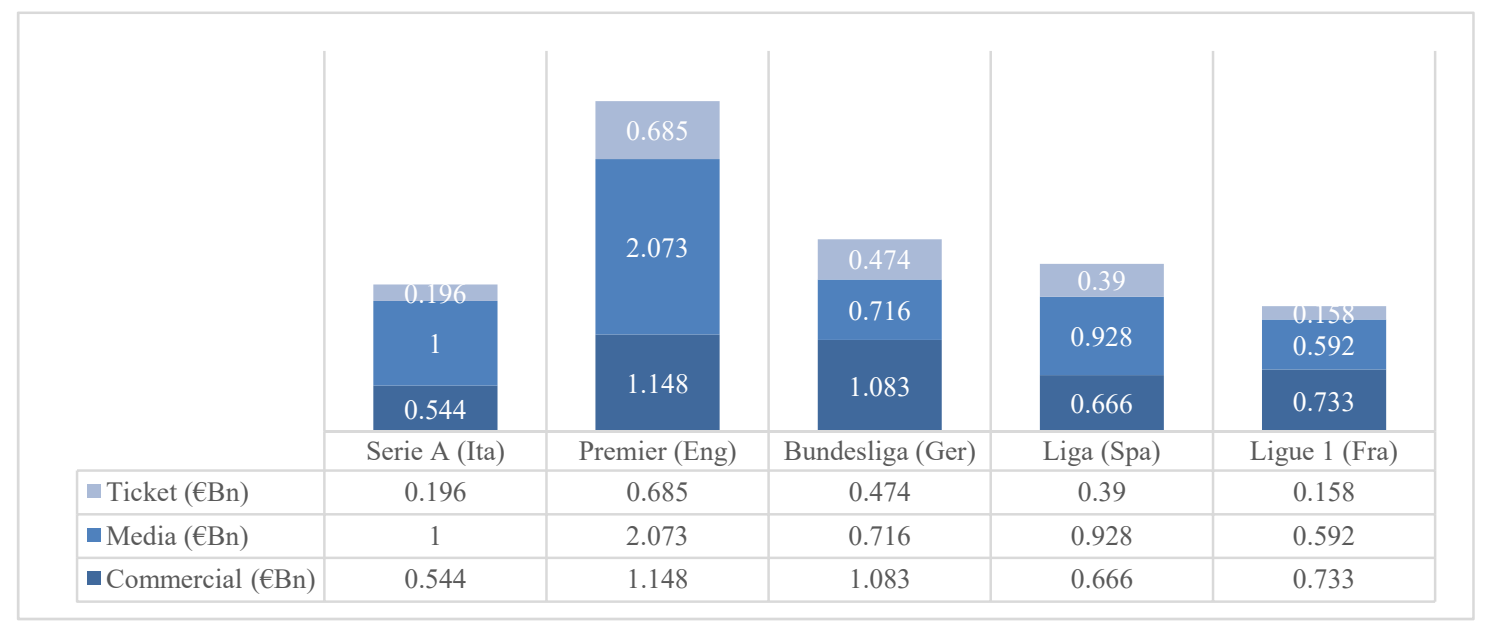

Figure 4. Comparison in European Top League Commercial, Media and Gate Receipt Revenues (Data in $€$ billion)

Breaking down the items that compose the revenues, it is highlighted that the Serie A has critical issues in recording revenues from the sale of tickets and merchandising. In the commercial area, in fact, Serie A holds the last position, showing that in Italy there is not an efficient culture in promoting activities which deviate from the core business of football club.

What saves the Serie A is attributable to revenues from the media. In fact, Serie A recorded in 2014 revenues from the sale of TV rights to around 1 billion euro, preceded exclusively by the English Premier League. In each country, however, the television rights are allocated in a different way (Note 8) and then the aggregate value of revenues from the sale of television rights is a purely comparative indicator that does not indicate whether the clubs within a sports league benefit on an equal footing or less of these revenues.

\section{The relationship between Economic-Financial Ratios and Club Performance in the Serie A}

\subsection{Data}

The primary data were collected by analysing the annual financial statements of Serie A clubs for the period 2011-2015. The data are referred to individual financial statements.

We extrapolated financial data from the databases Amadeus Bureau van Dijk and Thomson Reuters Eikon, and using the most famous Italian web sites that deal with Italian football industry (Note 9).

In total, we observed 145 cases for each financial indicator examined (discussed below) as well as club performance in Serie A with regards to 29 clubs that participated in Serie A during the period analysed.

The most commonly used method for financial statement analysis is ratio analysis. Ratio analysis is "the expression and mathematical interpretation of the relationship between two items aimed to be examined in the financial statements" (Ecer \& Boyukaslan, 2014).

The financial ratios used in this study are represented in Table 1.

Table 1. Financial ratios

\begin{tabular}{|c|c|c|c|}
\hline $\begin{array}{l}\text { Financial } \\
\text { indicators }\end{array}$ & Formulation & Aim & Variable \\
\hline \multirow[t]{4}{*}{ Profitability } & Wages/Turnover & $\begin{array}{l}\text { Under } \\
67 \%\end{array}$ & WageTurn \\
\hline & $\begin{array}{l}\text { Turnover increase }(\%)=(\text { This year's Turnover }- \text { last year's Turnover }) / \text { last year's } \\
\text { Turnover }\end{array}$ & Maximum & TurnoverIncrease \\
\hline & Profit $(\%)=$ Net Profit/ Turnover & Maximum & Profit \\
\hline & Net Profit/Total Asset & Maximum & ProfAsset \\
\hline \multirow[t]{2}{*}{ Liability } & Total Liabilities/Total Asset & Minimum & LiabAss \\
\hline & Total Liabilities/Equity & Minimum & LiabEquity \\
\hline
\end{tabular}


Profitability indicators are used in interpreting the profitability level which is the final aim of the business. The production function of football is linked to the sports entertainment to audiences offered in the matches. Therefore, the players are essential elements to develop team production. They represent one of the main items of the expenses including the wages and the amortization linked to them. Thus, it is useful to look at the proportion of resources used to maintain sporting performance (Barajas \& Rodriguez, 2010). We examine this through the ratio of Wages/Turnover. Késenne (2009) argues that this proportion must be placed under the 67\% for profit maximizing clubs. Moreover, we use the ratio Turnover increase that shows the organisation's ability to record revenues and the ratio Profit (\%) that shows the organisation's ability to generate potential return for its owners. At the end, the Net Profit/Total asset ratio could highlight the profitability of the assets.

Liability indicators are considered to interpret the relationship between business' equity capital and liabilities (Ecer \& Boyukaslan, 2014). We used the ratio Total Liabilities/Total Asset to indicate the portion of the business investments covered by the liabilities. The financial risk of the business increases if this ratio is high. In any case, it should be less than $100 \%$; in the opposite case, the company will not be able to face its debt using the assets it owns but it should resort to further borrowing. Another ratio useful is Total liabilities/Equity that expresses the relationship between business' liabilities and equity capital. The firm's risk increases when the amount of the liability is higher than equity capital.

The variable used to explain the in-field performances is the ranking of the clubs in Serie A seasons.

\subsection{Statistical Methodology and Results}

The financial and sporting performance data have been analyzed using R software.

In order to found empirical evidences of the causal relationships between sporting performance (effect) and several predictors (causes), it has to be performed a multiple regression analysis. This kind of analysis is able to deal with quantitative dependent variable using a number of independent variables as explanatory factors.

Firstly, a correlation analysis is performed. The correlation is a useful tool to get an overview about the strength of the relationships among variables, but with no causality hypothesis involved.

The interpretation of the correlation coefficients will concern only about the significance ones.

The null hypothesis about the Pearson Correlation Coefficient is that:

$$
\begin{aligned}
& H_{0}: \rho=0 \\
& H_{1}: \rho \neq 0
\end{aligned}
$$

It means that rejecting the null hypothesis (p-value $<0.05)$ will lead to assume the correlation as significantly different from zero. On the other hand, with a p-value $>0.05$, the correlation can be assumed as equal to zero.

The league rank is, as obvious, linked in discordant way with the sporting performances. It means that more a team is used to attend Serie A, it will be better its average ranking. The dependent variable assumed as proxy of sporting performance ("Serie A Rank") has as lowest value (rank=1) the best outcome and with highest value

\begin{tabular}{|c|c|c|c|c|c|c|c|c|}
\hline & $\mathrm{N}^{\circ}$ Serie A & $\begin{array}{l}\text { Stadium } \\
\text { Capacity }\end{array}$ & ProfAsset & LiabEquity & LiabAss & WageTurn & $\begin{array}{l}\text { Turnover } \\
\text { Increase }\end{array}$ & Profit \\
\hline $\begin{array}{l}\text { League } \\
\underline{\text { Rank }}\end{array}$ & $-0,499$ & $-0,559$ & $-0,092$ & 0,241 & 0,063 & $-0,396$ & $-0,103$ & 0,024 \\
\hline $\begin{array}{l}\text { p-value of } \\
\underline{\text { Test }}\end{array}$ & 0 & 0 & 0,9003 & 0,0154 & 0,659 & 0,001 & 0,4335 & 0,602 \\
\hline
\end{tabular}
$($ rank $=20)$ the worst (Figure 5). 


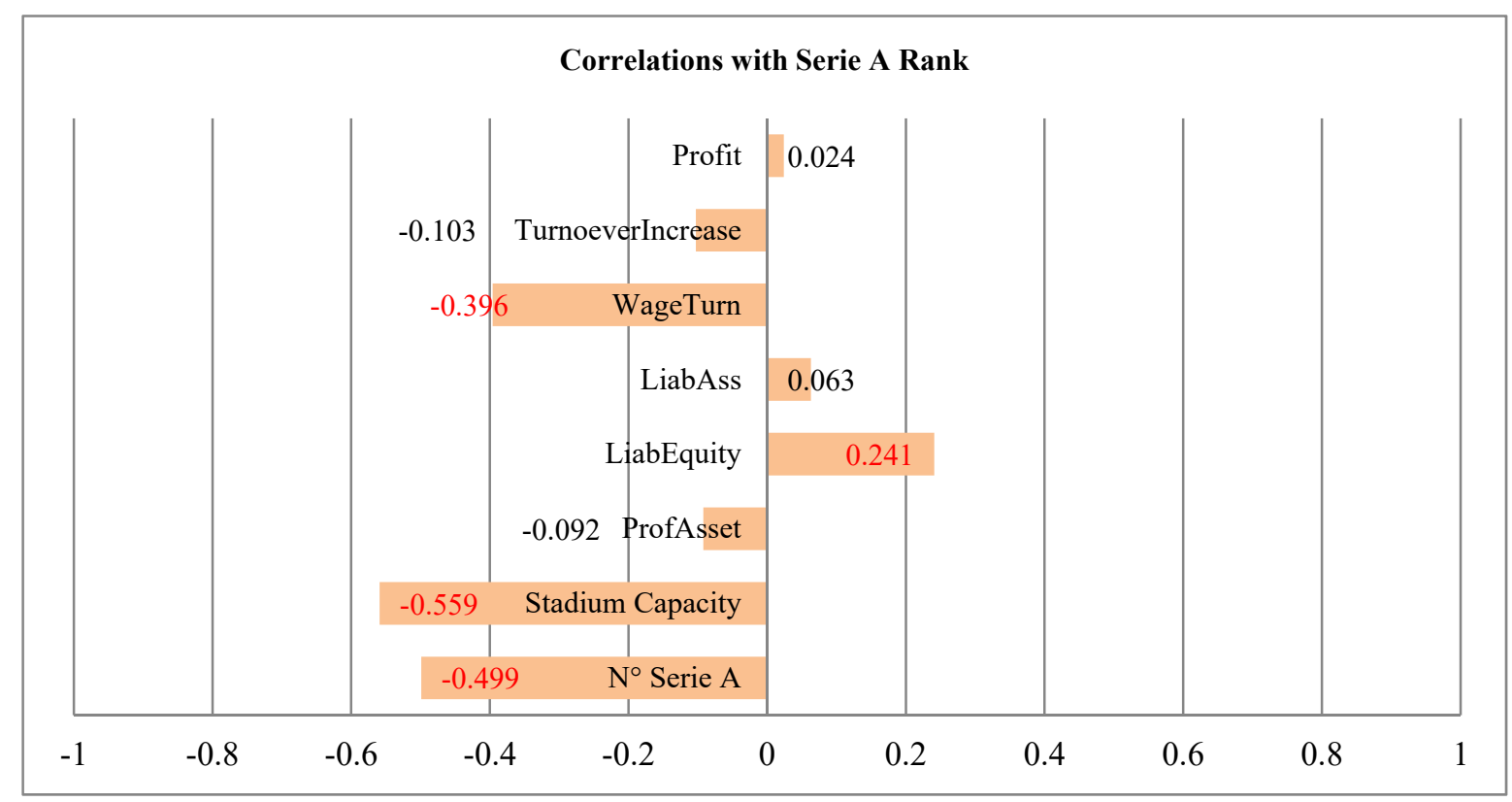

Figure 5. Correlations in Italian Serie A between financial indicators and League Rank (in red p value $<0.05$ ).

Only 4 correlations are significant

Another strong relationship is between league rank and stadium capacity. Bigger is the stadium, better will be the rank. That's of course a natural relation: bigger cities usually have stadium with higher capacity and the stronger teams. The stadium is one of the major sources of team revenues, in terms of both gate receipts and ancillary spending. Attendance at games means that teams can record revenues not only from the gate but also from other concessions which include parking and hospitality. So, according to the literature (Buraimo, 2008), it can be said that the stadium capacity influences the sporting performance positively in Italy too.

It is more interesting the relationship between the ratio Liabilities/equity and the sports performance; more the football clubs increase their indebtedness without using their equity, worst will be the final ranking expected. This means that a heavily indebted football team is not able to reach high sporting performances. This is linked to the fact that such a company does not have the necessary leeway to make new investments and to renew its tangible and intangible assets. Consequently, this will depend exclusively on the possibility of finding new lenders (Caramiello, Di Lazzaro, \& Fiori, 2003). It can be said that in Serie A, the best sporting performances are achieved by those football teams that do not leverage the debt capital.

Finally, the last significant correlation is with the ratio Wages/Turnover but in reverse. The direction of the relation is negative; it means that more the football clubs invest their revenues in wages, it will be better their final rank. In other words, to improve the sporting performance it must be done huge investments in wages, but the best choice is to do it using their own patrimonies. This result is according to part of literature (Figure 6) (Lago, Baroncelli, \& Szymanski, 2004).

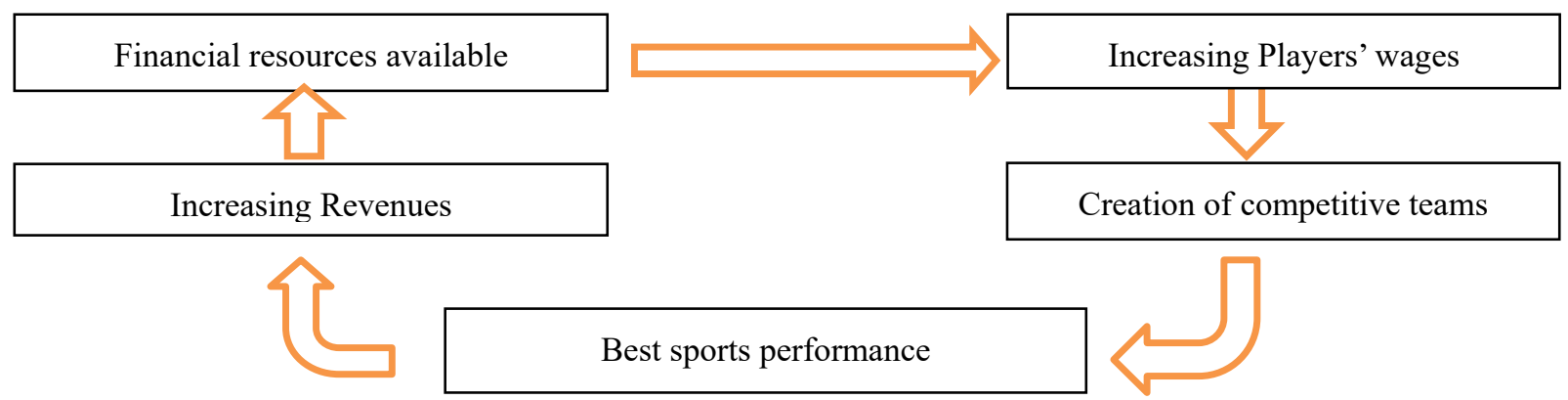

Figure 6. Virtuous circle between sports and financial performance

Source: (Lago, Baroncelli, \& Szymanski, 2004). 
As known in literature (Note 10), to perform a multiple regression analysis it is required a transformation to make data as much as possible normal and symmetric. The variable "WageTurn" shows a strong asymmetric behavior:

The logarithmic transformation improves the symmetry and the density function shows a pattern more similar to the normal distribution (Figure 7 and Figure 8).

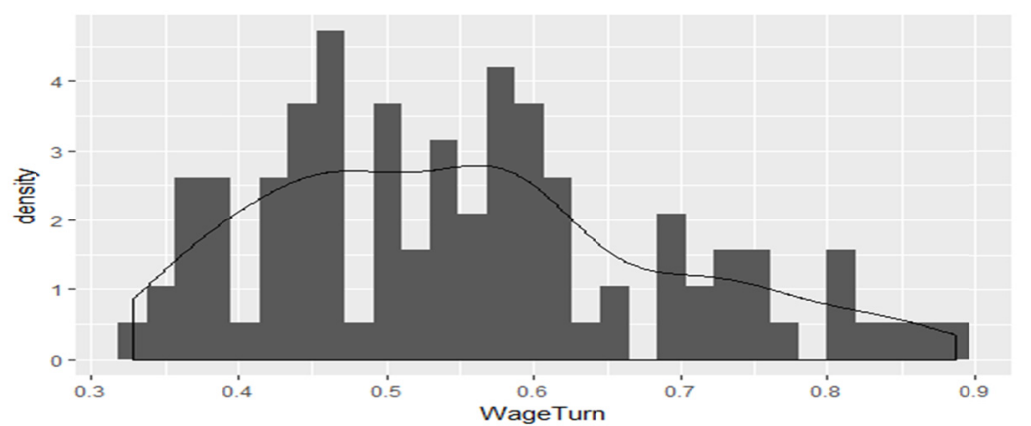

Figure 7. Histogram of density of the variable "WageTurn": the variable is positively asymmetric and not normal distributed

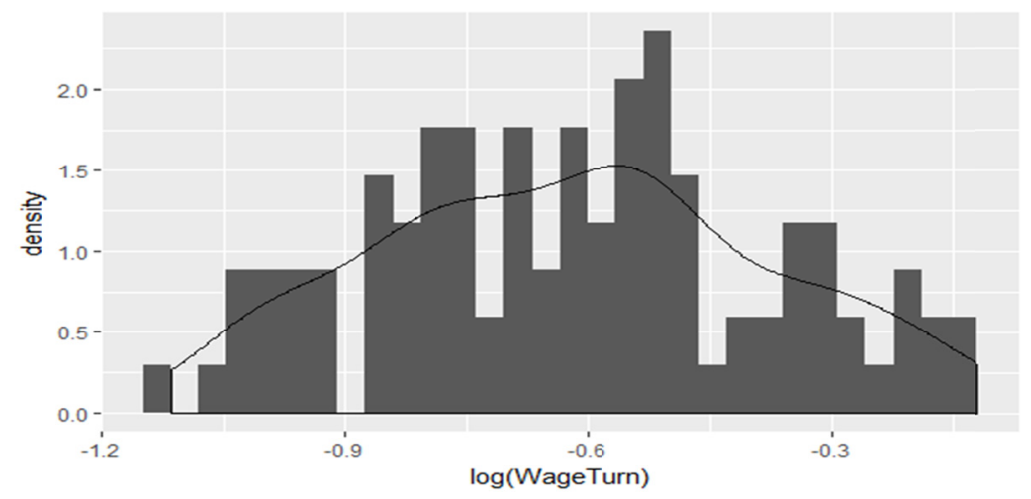

Figure 8. Histogram of density of the logarithmic transformation of the variable "WageTurn": the variable is slightly positively asymmetric and more alike to the normal distribution

The asymmetry index and the D'agostino test (Anscombe \& Glynn, 1983) allow to keep the transformation and to continue with the multiple regression analysis:

\begin{tabular}{lll}
\hline & WageTurn & Log(WageTurn) \\
\hline Skewness & 0.53 & 0.077 \\
z-value & 2.17 & 0.33 \\
$P$-value(HO=symmetry) & 0.029 & 0.742 \\
\hline
\end{tabular}

The test doesn't reject the null hypothesis of symmetric data in the second sample, the one with logarithmic transformation.

With the stepwise model selection approach (Note 11), the final estimated model according to different criterion of evaluation (overall F-tests and goodness of fit measures) is the following:

'Ranking ` = Mean_TIFL + Stadium capacity + LiabAss + log(WageTurn $)+$ TurnoverIncrease + Profit 


\begin{tabular}{|c|c|c|c|c|c|}
\hline \multicolumn{6}{|l|}{ Coefficients: } \\
\hline & Estimate & Std. Error & $\mathrm{t}$ value & $\operatorname{Pr}(>|t|)$ & \\
\hline (Intercept) & 5.14886 & 4.37532 & 1.177 & 0.244535 & \\
\hline Mean_TIFL & -5.27422 & 2.48500 & -2.122 & 0.038493 & $*$ \\
\hline Stadium cap. & -0.11772 & 0.03099 & -3.799 & 0.000376 & $* * *$ \\
\hline LiabAss & 5.89092 & 3.16266 & 1.863 & 0.068058 & \\
\hline $\log$ (WageTurn) & -12.73440 & 3.27034 & -3.894 & 0.000278 & $* * *$ \\
\hline TurnoverIncrease & -6.52489 & 2.57731 & -2.532 & 0.014353 & $*$ \\
\hline Profit & -12.58975 & 3.88009 & -3.245 & 0.002039 & $* *$ \\
\hline
\end{tabular}

Note. Multiple R-squared: 0.5904, Adjusted R-squared: 0.544 F-statistic: 12.73 on 6 and 53 DF,

p-value: $<0.0001$

The overall $\mathrm{F}$ test allows us to assume the model as valid. The percentage of variability of the dependent variable explained by the predictors is close to $60 \%$, and the penalization for the numbers of predictors leads to have an adjusted $R^{2}$ of 0.544 , therefore the overall explanatory power of the model is acceptable.

The values of the Vif index (Note 12) always are below the critical values and they show that multicollinearity is not an issue in this dataset, figuring out an absence of systematic bias of the estimation due to multicollinearity:

\begin{tabular}{lllllll}
\hline Variable & Mean_TIFL & Stadium & LiabAss & Log(WageTurn) & TurnoverIncrease & Profit \\
\hline VIF & 1.460291 & 1.660595 & 1.289745 & 2.302492 & 1.260567 & 1.947528 \\
\hline
\end{tabular}

The variables analyzed in correlation table keep the direction of effect also in Multiple regression analysis. The new variable rising as determinants of sporting performance are the Liability asset, the Turnover increase and the Profit.

\section{Conclusion and Implications}

This paper confirms empirically that Italian clubs that are in better financial health achieve the best sporting performance.

It has been shown that in Serie A, the best sporting performances are achieved by those football teams that are not indebted.

Moreover, we highlight that the stadium is one of the major sources of revenues. As a consequence, the teams that play in the biggest stadiums have more on-field success. The football clubs that can afford higher wages are the companies which have greater revenues. Furthermore, we point out that Italian football clubs which can afford the highest wages will have the highest level of on-field performance, as judged by the final league position. This correlates with the "virtuous circle" promoted by the literature (Lago, Baroncelli, \& Szymanski, 2004).

These results show that Italian football industry acts as a hybrid between the profit maximization approach and win maximization approach because the most successful teams are also the most solid from an economic and financial perspective.

The entry of foreign investors could change this trend. In fact, they are likely to be less discerning regarding social returns and may prefer to focus on the club's financial performance. Moreover, they could act as money-injecting private investors who are often referred to as "sugar daddies". It has been argued that private investors increase team investment (i.e., through player salaries and net team transfer expenditure) which in turn drives sporting success and revenues as shown in literature (Lang, Grossmann, \& Theiler, 2011). So, this could alter the results obtained in this paper. In fact, in our study, only 8 out of 145 analysed cases have the presence of foreign investors. In fact, during the period under review (2011-2015), only A.S. Roma and F.C. Inter from 2013 were owned by foreign investors.

\section{References}

Andreff, W. (2011). Some comparative economics of the organization of sports: Competition and regulation in north American vs. European professional team sports leagues. European Journal of Comparative Economics, 8(1), 3-27.

Andreff, W., \& Staudohar, P. (2000). The evolving model of professional sport finance. Journal of Sports 
Economics, 257-276. https://doi.org/10.1177/152700250000100304

Anscombe, F., \& Glynn, W. (1983). Distribution of the Kurtosis Statistic b2 for Normal Samples. Biometrika, 227-234. https://doi.org/10.1093/biomet/70.1.227

Barajas, A., \& Rodriguez, P. (2010). Spanish Football Clubs' Finances: Crisis and Player Salaries. International Journal of Sport Finance, 52-66.

Baroncelli, A., \& Caruso, R. (2011). The Organization and Economics of Italian Serie A: a Brief Overall View. Rivista di diritto ed economia dello sport, 7(2), 67-85.

Boeri, T., \& Severgnini, B. (2014). The decline of professional football in Italy. Handbook on the Economics of Professional Football, 322. https://doi.org/10.4337/9781781003176.00027

Bonini, F. (2008). Sport, azienda e politica: il Milan di Silvio Berlusconi". Memoria e ricerca.

Brunkhorst, J. P., \& Fenn, A. J. (2010). Profit Maximization in The National Footbal League. The Journal of Applied Business Research, 45-58.

Buraimo, B. (2008). Stadium Attendance and Television Audience Demand in English League Football. Managerial and decision economics, 513-523. https://doi.org/10.1002/mde.1421

Calcio e Finanza. (2016, May 25). Calcio e Finanza. Retrieved from http://www.calcioefinanza.it.

Caramiello, C., Di Lazzaro, F., \& Fiori, G. (2003). Indici di bilancio. Strumenti per l'analisi della gestione aziendale. Giuffrè.

Ecer, F., \& Boyukaslan, A. (2014). Measuring Performances of Football Clubs Using Financial Ratios: The Gray Relational Analysis Approach. American Journal of Economics, 62-71.

Forgione, A. (2015). Dov'è la vittoria. Magenes.

Garcia-del-Barro, P., \& Szymanski, S. (2006). Goal! Profit maximization and win maximization in football leagues. International Association of Sports Economists.

Gelmini, L. (2014). Le società di calcio professionistiche nella prospettiva dell'economia d'azienda. Modelli di bilancio e valore economico dei club. Giuffrè editore.

Ginsborg, P. (1989). Storia d'Italia dal dopoguerra a oggi. Einaudi.

Hoehn, T., \& Szymanski, S. (1999). The Americanization of European Football. Economic Policy, 203-240. https://doi.org/10.1111/1468-0327.00048

Iaria, M. (2016, March 10). Serie A, ecco i soldi della tv: per la Juve 103 milioni, 80 al Milan, 78 all'Inter. Gazzetta dello Sport.

Késenne, S. (1994). Win maximization and the distribution of playing talent in professional team sports.

Késenne, S. (1996). League management in professional team sports with win maximizing clubs. European Journal for Sport Management, 2(2), 14-22.

Késenne, S. (2009). The financial situation of the Belgian 'Jupiler League': Are players overpaid in a win-maximization league? Football and Finance Congress. Paderborn.

Kutner, M., Nachtsheim, C., \& John, N. (2004). Applied Linear Regression Models (4th ed.). Blacklick: McGraw-Hill.

Lago, U., Baroncelli, A., \& Szymanski, S. (2004). Il business del calcio: successi sportivi e rovesci finanziari. Milano: Egea.

Lang, M., Grossmann, M., \& Theiler, P. (2011). The sugar daddy's game: How wealthy investors change competition in Professional Team Sports. Journal of Institutional and Theoretical Economics, 557-577.

Morrow, S. (2013). Football Club Financial Reporting: Time for a New Model? Sport, Business and Management: An international Journal.

Neale, W. C. (1964). The Peculiar Economics of Professional Sports: A Contribution to the Theory of the Firm in Sporting Competition and in Market Competition. The Quarterly Journal of Economics, 78(1), 1-14. https://doi.org/10.2307/1880543

Rohde, M., \& Breuer, C. (2016). The financial impact of (Foreign) private investors on team investments and profits in professional football: empirical evidence from the Premier League. Red Fame. https://doi.org/10.11114/aef.v3i2.1366 
Rottenberg, S. (1956). The Baseball Players' Labor Market. The Journal of Political Economy, 64(3), 242-258. https://doi.org/10.1086/257790

Sakia, R. (1992). The Box-Cox Transformation Technique: A review. Journal of the Royal Statistical Society, 41, 169-178. https://doi.org/10.2307/2348250

Sanders, A., Heys, B., Ravenscroft, N., \& Burdsey, D. (2014). Making a difference: the power of football in the community. Soccer \& Society, 15(3), 411-429. https://doi.org/10.1080/14660970.2012.692675

SAS Institute Inc. (n.d.). SAS/STAT ${ }^{8} 9.1$. User’s Guide. Cary, NC: SAS Publishing.

Sloane, P. (1971). The Economics of Professional Football: The Football Club as a Utility Maximiser. Scottish Journal of Political Economy, 17(2), 121-146. https://doi.org/10.1111/j.1467-9485.1971.tb00979.x

Wilson, R., \& Plumley, D. (2013). The relationship between ownership structure and club performance in the English Premier League. Sport, Business and Management: An International Journal, 19-36. https://doi.org/10.1108/20426781311316889

\section{Notes}

Note 1. An example of need is the commitment to the club and desire to contribute to the financial needs of clubs. Morrow (2013) writes about it: “(..) small share holdings (have) a buy and hold strategy and (render) the traditional function of financial statement as informing investment decision making largely irrelevant...".

Note 2. Among the most famous figures, there are certainly the families of Agnelli, Berlusconi and Moratti in the Northern Italy, the Sensis and Cragnottis in Rome, but also Tanzi's family in Parma. Even in the last 10 years, the affirmation and the ascent of clubs like Napoli, Palermo and Fiorentina have confirmed the trend where the ownership of football clubs is highly concentrated in the hands of a single owner.

Note 3. For example, Silvio Berlusconi (A.C.Milan's owner until 2016) has been using football as an instrument of political propaganda and as a scatter symbol of himself, abandoning the idea to realize positive economic-financial results. From an economic-financial approach, A.C. Milan has often realized net losses that were regularly covered by Berlusconi's holding company, Fininvest. In several years, Fininvest gave further support to A.C. Milan purchasing the tax losses, used to save taxes with the application of the national consolidated tax scheme. To further informations, see (Bonini, 2008).

Note 4. The migratory flow from the Southern Italy to the headquarters of Fiat was so great that - at the end of the sixties - Turin (city of the headquarters of Juventus and of Fiat, located in Northern Italy) had become the third largest "Southern" city of Italy after Naples and Palermo. In this way, "The Football became a pretext to be accepted, the most immediate vehicle to feel integrated" (Forgione, 2015, pp.98).

In the early seventies, Juventus bought the Southern Italian player Anastasi who became "the living symbol of an entire social class, that one who reluctantly left the Southern Italy to go to earn a living in Northern factories" (Ginsborg, 1989).

Note 5. (Baroncelli \& Caruso, 2011, p. 74) say: "Thus, we may conclude that also in Italian football business a pure economic rationale does not apply to the football industry".

Note 6. FIGC issued Norme organizzative interne that include also the accounting policies.

Note 7. The calculation was carried out by adding the profits (losses) on 19 of the 20 teams that participated in the Serie A in the season $2014 \backslash 2015$. The twentieth team is the Parma F.C. - failed during that season - that did not disclose its financial statement.

Note 8. I.e. In Premier League the national and international media rights and the so-called central commercial revenues, are for the $50 \%$ shared equally. Another $25 \%$ of the total is assigned based on the number of times that a match is broadcast live. And this the so-called "Facility Fee" that it is very significant if we consider that the games broadcast on television are less than $50 \%$ of those effectively played. (Calcio e Finanza, 2016).

In Serie A, the $40 \%$ of media rights are splitted into equal parts. The remaining $30 \%$ will be divided into basis of catchment areas $(25 \%$ as established by research on typhoid and $5 \%$ by the Istat data on the resident population in the municipality in which the team plays) and the other $30 \%$ will be distributed according to the sport results ( $10 \%$ relating to the sporting history, $15 \%$ the previous five years and $5 \%$ to the current season). (Iaria, 2016).

Note 9. www.calcioefinanza.it ; www.tifosobilanciato.it ; www.transfermarkt.it

Note 10. (Sakia, 1992). 
Note 11. (SAS Institute Inc.).

Note 12. (Kutner, Nachtsheim, \& John, 2004).

\section{Copyrights}

Copyright for this article is retained by the author(s), with first publication rights granted to the journal.

This is an open-access article distributed under the terms and conditions of the Creative Commons Attribution license (http://creativecommons.org/licenses/by/4.0/). 